\title{
GEOLOGICAL AND TECTONIC SETTING OF THE GUANIAMO KIMBERLITE SHEETS, SOUTH - WEST VENEZUELA
}

\author{
Dominic Channer ${ }^{1}$, Andrei Egorov ${ }^{1}$ and Felix Kaminsky ${ }^{2}$ \\ ${ }^{1}$ Guaniamo Mining Company, Venezuela ${ }^{2}$ KMD Diamond Exploration Ltd, Canada
}

\section{INTRODUCTION}

The Guaniamo area is located in western Bolivar State, Venezuela, and is one of the most promising diamondiferous areas in South America. Diamondiferous, tropically weathered, kimberlite sheets (i.e., discordant horizontal dikes, see Howard, 1991) were discovered by Baxter - Brown, Cooper, and Drew within the Quebrada Grande river basin in 1982. Petrographic, geochemical, mineralogical, and isotopic studies of unweathered drill core confirmed that the sheets are kimberlite (Channer et al., 1998; Kaminsky et al., 1997).

In this abstract we describe the geological and structural settings and characteristics of the Guaniamo kimberlite sheets, their mode of emplacement and we discuss aspects of their regional geologic and tectonic relationships.

\section{LOCAL GEOLOGY AND STRUCTURE}

Kimberlites occur predominantly in a granodioritic domain (domain I), which is limited to the south by contacts with younger granites and to the east with volcanic and volcaniclastic rocks of the Caicara formation. This granodioritic domain is dominated by a north to north - west structural trend, expressed in high angle faults and fractures, in recent topography, and in foliated granodiorite and abundant gabbro dikes. In addition, a series of north - west trending, gently north east dipping fractures is also well developed. These fractures show a regional easterly dip of 5 to $20^{\circ}$ and have only been observed in association with ultramafic intrusions, including kimberlite and lamprophyre (see Channer et al. 2001).

The southern limit of domain I is defined by the north - east trending Puente Palo fault zone. This forms a steep sided, linear valley, and is the contact between older Cuchivero group rocks to the north and younger granites to the south. On a regional scale, the Puente Palo trend can be traced to the Guri fault system in the Imataca province. Exposures of volcaniclastic rocks in this fault zone exhibit intense north - east oriented foliations. To the north of the Puente Palo fault at least three other important north - east trending fault zones cross the Quebrada Grande corridor.

\section{STRUCTURAL CHARACTERISTICS}

Kimberlite strike directions are principally north west with a subsidiary north - east direction. Regional dips are to the east or south - east and range from sub horizontal to $\sim 20^{\circ}$. At Comisario, however, dips of $35^{\circ}$ to $60^{\circ}$ to the south - east, into the Puente Palo valley, have been recorded.

There are at least eight kimberlite sheets covering $10 \mathrm{~km}$ of north - westerly strike, and a width of $\sim 5 \mathrm{~km}$. These are: Bicicleta - Desayuno, Los Indios - $024-\mathrm{La}$ Peinilla - Cordero, Hueso Duro - La Ceniza - 039, Nueva Bulla, Bulla de las Mujeres - La Hoya, Desengaño - Candado, and El Tigre. Kimberlite at deeper levels in Bicicleta represents another possible sheet of as yet unknown size. Kimberlite has been found at elevations ranging from $145 \mathrm{~m}$ a.s.l (above sea level) in Bicicleta to $410 \mathrm{~m}$ a.s.1 in Desengaño, giving a minimum vertical range of $265 \mathrm{~m}$. Including sheets which are structurally higher than Desengaño (e.g., Los Indios, El Tigre), we estimate that the known kimberlite sheets cover a vertical range of 400 to $500 \mathrm{~m}$. Adjacent sheets are separated by $50-125 \mathrm{~m}$ (perpendicular to dip). The maximum down dip extent proven by drilling for a single sheet is $1 \mathrm{~km}$ for La Ceniza, but the final extent of the this sheet is unknown. Kimberlite sheets pass without break from granodiorite to gabbro, occasionally changing in orientation upon crossing contacts. Footwall surfaces show local topographical variation in the order of 5 to $25 \mathrm{~m}$. In some places kimberlite veins splay off from the kimberlite sheet at high dip angles. These veins are thin $(<10 \mathrm{~cm})$ and are unlikely to extend far from the main kimberlite sheet. No veins or dikes have been observed which connect one kimberlite sheet to the next sheet, some 50 to 125 $\mathrm{m}$ above or below. However, in numerous boreholes zones of kimberlite veins have been found at depths well separated from the main kimberlite sheet, sometimes above (e.g., La Ceniza) and sometimes below (e.g., Bicicleta).

The thickness of the kimberlite sheets varies from $3.7 \mathrm{~m}$ down to $10 \mathrm{~cm}$ and may change rapidly over 10 $\mathrm{m}$. Analysis of drill data shows that there is no significant difference between the range and mean thickness of weathered saprolitic kimberlite (mean 1.02 m, s.d. $0.81 \mathrm{~m}, \mathrm{n}=91$ ) compared with fresh kimberlite (mean $0.91 \mathrm{~m}$, s.d. $0.82 \mathrm{~m}, \mathrm{n}=96$ ). This is consistent 
with the observation that primary kimberlite textures are preserved in the saprolite, i.e., no significant volume change has occurred, in contrast to weathered kimberlite at higher levels in the soil profile.

Aerial photograph and topography interpretation has shown a large quantity of fractures of different directions and dimensions. Some are local, while others form part of regional fault systems. The principal Quebrada Grande north - west trending lineament, about $6 \mathrm{~km}$ wide, consists of at least three main directions of fault groups: $345-335^{\circ}, 320-325^{\circ}$ and $300-$ $310^{\circ}$. Extended zones containing high densities of north - west trending faults (e.g., Desayuno - Bicicleta, Los Indios, Desengaño) separate blocks with relatively low densities of north - west trending faults (e.g., La Ceniza, Candado, La Hoya).

The north - west structural trend is complicated by cross - cutting north - east trending fault systems. Moving in a north - west direction from the Puente Palo fault, there are three additional north - east trending fault zones of high fracture density. The width of these zones varies from $450 \mathrm{~m}$ (El Milagro fault) to $600 \mathrm{~m}$ (Los Indios fault) and about $1 \mathrm{~km}$ (La Ceniza fault). The size of the lateral displacements across these fault zones increases progressively from about ten meters inside the El Milagro fault to $100-150 \mathrm{~m}$ within the Los Indios fault and more than $500 \mathrm{~m}$ inside of the $\mathrm{La}$ Ceniza fault zone.

\section{LOS INDIOS - 024 KIMBERLITE SHEET}

In Los Indios - 024, through a combination of drill and outcrop data, the kimberlite sheet has been shown to be continuous over $2 \mathrm{~km}$ along strike and $500 \mathrm{~m}$ down dip. Additional geological data (outcrops, drill holes, miners' pits, and stream samples) show that this section is part of a much larger sheet, which extends for at least $8 \mathrm{~km}$, with occasional breaks.

In cross - section the Los Indios kimberlite sheet shows a structural low point, around $260 \mathrm{~m}$ a.s.1, in the northern part. Away from this point it rises to the north and west, while to the south it undulates, showing additional highs and lows and small possible fault displacements. The Los Indios sheet has a general north - west strike and an overall north - east dip of 6 to $8^{\circ}$, showing regularity over $1 \mathrm{~km}$. Variations occur over distances of $50-100 \mathrm{~m}$, forming structural highs and lows, elongated in a down dip direction and with amplitudes from high to low of 25 to $30 \mathrm{~m}$.

The kimberlite sheet is characterized by variable thickness from $<0.5 \mathrm{~m}$ up to $2.5 \mathrm{~m}$. Zones of relatively consistent thickness occur over at least $300 \mathrm{~m}$. In rare cases variations from 2.5 to $0.5 \mathrm{~m}$ may occur over $\sim 10$ $\mathrm{m}$. Geological models of this area show a correlation between easterly trending zones of low thickness, and the structural highs shown by the footwall contours.
Zones of thicker kimberlite coincide with structural lows but spread out beyond them.

Data obtained from drilling and miners' workings have shown that there are zones where the kimberlite sheet fingers out in a series of veins and fractures, only to pick up again after a gap of a few hundred meters, normally at a similar structural level. Between Los Indios north and La Lapa, for example, drill holes 112 and 113 showed increased fracture counts, but no kimberlite, at the expected intersection zones. There is an elevation difference of approximately $40 \mathrm{~m}$ between Los Indios and La Lapa, only slightly more than the amplitude from structural highs to lows in Los Indios and La Ceniza. Had there been greater magma driving force at the opposing fracture tips, it is likely that they would have connected.

\section{THE ROLE OF FAULTING}

No evidence for penetrative deformation of kimberlite has been observed. Occasionally a slight fabric is developed at the wall rock contact, reflecting minor syn - or post - emplacement movement. The available geological data indicate that any significant vertical or lateral fault movement predated kimberlite emplacement, and that the kimberlite sheets represent a multi - level system and not one single layer, subsequently separated by brittle faulting. The following observations are relevant to this argument:

a) Drilling in the north of Los Indios has intersected first the El Tigre sheet, and then the Los Indios sheet, the two being separated vertically by $68 \mathrm{~m}$.

b) Drilling in Bicicleta and La Ceniza has found kimberlite veins at significant distances above and below the kimberlite sheets.

c) Kimberlite sheets such as Bicicleta and Hueso Duro - La Ceniza show smooth profiles across north west trending fault zones in the Quebrada Grande valley, with drill hole data implying a maximum of $10 \mathrm{~m}$ of post - kimberlite fault offset.

d) Drilling within major north - east trending fault zones showed continuity of the kimberlite sheets (e.g., Desayuno in the Milagro fault zone, Los Indios in the Los Indios fault, La Ceniza in the La Ceniza fault).

Hence, the available data indicate that post intrusion fault offset of kimberlite sheets is small (i.e., not $>20 \mathrm{~m}$ vertically). Within the north - east trending fault zones, the kimberlite sheet geometry is irregular but there does not appear to have been significant post emplacement faulting. It should be noted that there are at least three levels of alluvial terraces along the Puente Palo valley, occurring up to $15 \mathrm{~m}$ vertically above the bedrock contact, and showing that some areas within Guaniamo have experienced neotectonic activity. 


\section{MODE OF EMPLACEMENT}

The sheets most likely were emplaced by hydrofracturing, i.e., in fractures whose propagation was driven by magma buoyancy (e.g., Spence \& Turcotte, 1990) and pressure. Supporting evidence includes: fracture orientation independent of pre existing rock fabrics, spaced fractures and veins occurring close to, and sub - parallel with, the kimberlite sheets, abundant veins and fractures at termini of sheets, generally smooth hanging wall and footwall contacts, and localities with high xenolith contents. These characteristics have been observed for other kimberlite sheets (e.g., Andrews \& Emeleus, 1975) and diabase sills (Leaman, 1995) and sheets (Howard, 1991), for which a similar emplacement mechanism was proposed. Prior to kimberlite emplacement in Guaniamo the area had been strongly faulted, forming a block mosaic.

The kimberlite sheets do not infill a prior joint system. None of the typical textures of joint surfaces have been observed on footwall exposures, and the dimensions of individual sheets are much greater than normal joint dimensions (see Pollard \& Aydin, 1988).

Studies of kimberlite sheets in Greenland (Andrews \& Emeleus, 1975) showed that the kimberlite only exploited pre - existing fractures that were of favorable orientation at the time of kimberlite emplacement. Some isolated examples of this nature have been observed in Guaniamo. The structural characteristics of the Greenland kimberlite sheets show many similarities with Guaniamo and imply a similar emplacement mechanism, although the high local xenolith content in Guaniamo suggests more explosive emplacement. Features of the Greenland kimberlite sheets include:

a) The sheets in Greenland form five, shallow dipping, levels covering a $500 \mathrm{~m}$ vertical interval, with individual sheets up to $2 \mathrm{~km}$ in strike length.

b) The shallow dips appear to be primary. In Guaniamo the absence of overlying sediments makes it difficult to know if the shallow eastward dip of the sheets is primary or the result of slight rotation of fault blocks.

c) They only exploit older fractures when their orientation is favorable, otherwise they are independent of prior heterogeneities and respond only to the prevailing external stress field at emplacement.

d) Their dip direction may change significantly while the sheet remains continuous (c.f. La Peinilla in Guaniamo).

e) Sheets show evidence for multiple phases of intrusion, for dilation with preservation of screens, for termination against cross - faults, for platy cleavage adjacent to sheet contacts, and for collapse structures in jointed overlying granites.

f) The Greenland sheets have abundant mantle nodules and few local xenoliths, while the reverse is true for Guaniamo.

\section{Locations of feeder dikes}

Although near vertical feeder dikes have not been observed for the sheets, the Comisario kimberlite dips at $\sim 50^{\circ}$ to the south - east into the Puente Palo fault. This kimberlite is the closest candidate for a feeder and connects with a higher level kimberlite sheet, the direction of magma flow being upwards from south east to north - west. The following observations are pertinent to magma flow directions:

a) Imbricated xenoliths at Desengaño and Candado suggest magma flow vectors from east to west.

b) Several sheets show local pinching out and rising up to the north and south away from north - east trending fault zones (e.g., La Ceniza, Desayuno, Los Indios, and La Peinilla), implying north - west and south - east directed flows.

c) The gap of about $250 \mathrm{~m}$ between the kimberlite in Los Indios and La Lapa is consistent with two sheets propagating from the south - east and north - west, respectively, but being sufficiently far from their feeders not to have been able to join up.

d) In Desayuno, which lies within the north - east trending Milagro fault zone, there are abundant kimberlite veins that form a circular stockwork 80 $\mathrm{m}$ wide, above a potential blow or feeder location.

e) There is a general association of zones of thick kimberlite, greater than $2 \mathrm{~m}$, with structural lows in kimberlite sheets and with north - east trending faults (e.g., Desayuno, Los Indios, Candado, Comisario, and La Ceniza). Thicker kimberlite sheets, with more than one phase of intrusion, would be expected to be more common near to feeder zones.

The above data indicate that additional feeders may be located in the other north - east trending faults which occur to the north of the Puente Palo fault (e.g., La Ceniza, Los Indios, Milagro). These systems of transverse faults superimposed on north - west trending fractures formed zones of weakness within the crystalline basement, creating fault troughs divided by horst - like structures. The kimberlite sheets appear to have used these fractures, forming embayments in plan view and saucer - or T - shaped (but asymmetrical) bodies in cross - section (e.g., Desayuno, La Peinilla, Los Indios, La Ceniza). A similar relationship was shown for diabase sheets in Tasmania (Leaman, 1995). 


\section{DISCUSSION}

The presence of highly diamondiferous, multiple kimberlite sheets in a region of juvenile Proterozoic crust for which no Archean component to the sub lithospheric continental mantle has so far been determined, is unusual within the context of established models for diamondiferous kimberlites. The extremely high proportion of eclogitic diamonds is also noteworthy. Here we discuss some points, which are relevant to developing a model for this new type of diamond deposit.

\section{REGIONAL TECTONIC SETTING}

The Cuchivero province, part of the larger Ventuari - Tapajós (VTP) geochronological province, consists primarily of new, juvenile continental crust (1950 to $1800 \mathrm{Ma}$ ) formed as subduction - related magmatic arcs, which were accreted to the Imataca and Pastora provinces in the east (Tassinari \& Macambira, 1999). The ancient suture zone is interpreted to lie along the Río Caura. Extensive systems of horsts and grabens, with associated mafic magmatism, formed between $1500 \mathrm{Ma}$ and $1600 \mathrm{Ma}$ due to subduction related extension (Gibbs \& Barron, 1993). Extreme fractionation gave rise to intrusions such as the Parguaza granite (Mendoza, 1975). A north - west trending rift valley, the Cabruta - Ventuari rift, along which repeated mafic (e.g., gabbro), ultramafic (e.g., Guaniamo kimberlite, lamprophyre), and alkaline (e.g., Cerro Impacto carbonatite) magmatism has occurred, formed during this period of extension (e.g., MartinBellizia, 1972).

\section{REGIONAL GEOPHYSICS}

As part of the ECOGUAY project (Schmitz et al. 2002) a seismic refraction profile was made from east to west across the Pastora, Imataca, and Cuchivero provinces. The crustal thickness in the Cuchivero province is $46 \mathrm{~km}$ with an average velocity of $6.5 \mathrm{~km} / \mathrm{s}$; the upper mantle velocity is $8.1 \mathrm{~km} / \mathrm{s}$. Crust in the Pastora and Imataca provinces is slightly thinner at 42 $\mathrm{km}$. The measured Bouguer gravity anomaly profile varies from about $30 \mathrm{mGal}$ in the west to $-20 \mathrm{mGal}$ in the east and differs strongly from the calculated Bouguer gravity anomaly, made using a crustal density structure derived from the seismic velocity model. Schmitz et al. (2002) suggest that lateral variations in density are the cause of the observed Bouguer anomaly and that these variations could come from crust or mantle (e.g., relicts of subducted oceanic crust).

\section{DIAMOND AND HIGH PRESSURE MINERALS}

Guaniamo diamonds and their mineral inclusions have been studied in detail by Kaminsky et al. (2000), Sobolev et al. (1998), and more recently by Schulze et al. and Sobolev et al. (this volume). Results show that Guaniamo diamonds are overwhelmingly eclogitic in origin (at least $85 \%$ ) and that they formed at high temperatures (approx. $1200^{\circ} \mathrm{C}$ ) near the base of the lithosphere. These studies indicate that the eclogitic diamonds were formed in subducted oceanic crust.

\section{CONCLUSIONS}

Kimberlite sheets were emplaced in Guaniamo at $710 \mathrm{Ma}$, some $800 \mathrm{Ma}$ after deposition of the Proterozoic Roraima formation, and approximately 700 Ma after the last granitic and alkaline magmatism in the area. Subduction of oceanic crust beneath the Cuchivero province occurred from $1950 \mathrm{Ma}$ to between 1400 and $1200 \mathrm{Ma}$. Oceanic crust subducted during this period is the most likely source for the eclogite layers at the base of the lithosphere beneath Guaniamo.

The period from 1950 to $1450 \mathrm{Ma}$ represents a major phase of accretion of juvenile continental crust to the Amazonian Archean protocraton (i.e., the VTP, and the adjacent Rio Negro - Juruena (RNJP) province). The magmatic arcs were produced by subduction of oceanic lithosphere, which culminated in a collision between the Amazonian protocraton and another large craton, possibly Laurentia (Tassinari \& Macambira, 1999). The presence of highly diamondiferous kimberlite sheets in Guaniamo implies that much of the vast area represented by the VTP and RNJP is prospective for kimberlite intrusions, including pipes. Sheets were formed in domain I in Guaniamo due to strong faulting in the Quebrada Grande basin which favored multiple injections of kimberlite magma up fault zones, with sheets spreading out from these zones.

\section{REFERENCES}

Andrews, J.R., Emeleus, C.H., 1975. Structural aspects of kimberlite dike and sheet intrusion in south-west Greenland. Phys. Chem. Earth, 9: 43-50.

Channer, D.M.DeR., Cooper, R.E., Kaminsky, F.V., 1998. The Guaniamo diamond region, Bolivar State, Venezuela: A new kimberlite province. Extended Abstracts, $7^{\text {th }}$ International Kimberlite Conference, Cape Town, South Africa, April 1998, 144-146.

Channer, D.M.DeR., Egorov, A., Kaminsky, F.V., 2001. Geology and structure of the Guaniamo diamondiferous kimberlite sheets, South - west Venezuela. Revista Brasileira de Geociencias 31 (4), 615-630. 
Gibbs, A. K., Barron, C. N., 1993. Geology of the Guiana shield, Oxford University Press, 246p.

Howard, K.A., 1991. Intrusion of horizontal dikes: Tectonic significance of Middle Proterozoic Diabase sheets widespread in the upper crust of the southwestern United States. Jnl. Geophys. Research. 96, B7: 1246112478.

Kaminsky, F.V., Sablukov, S.M., Sablukova, L.I., 1997. Results of a petrographic, mineralogical, and geochemical study of kimberlites from the Los Indios and Desayuno sills, Guaniamo area, Venezuela. Report for Guaniamo Mining Company.

Kaminsky, F.V., Zakharchenko, O.D., Griffin, W.L., Channer, D.M.DeR., Khachatryan-Blinova, G.K., 2000. Diamond from the Guaniamo area, Venezuela. Canadian Mineralogist, 38: 1347-1370.

Leaman, D.E., 1995. Mechanics of sill emplacement: comments based on the Tasmanian dolerites. Aust. Jnl. Earth. Sci. 42: 151-155.

Martin-Bellizia, C., 1972. Paleotectónica del Escudo Guayana. IX Conferencia Geológica Inter - Guayanas, Ciudad Guayana, Venezuela, 1972. Boletín de Geología, Publicación Especial 6, 251-305.

Mendoza, V., 1975. Estudios geoquímicos del no-tectonizado granito rapakivi del Parguaza, noroeste Guayana Venezolana. Anais X Conferencia Geológica Interguayanas, Belem, Pará, Brasil, 628-656.

Pollard, D.D., Aydin, A., 1988. Progress in understanding jointing over the past century. Geol. Soc. Amer. Bulletin. 100: 1181-1204.

Schmitz, M., Chalbaud, D., Castillo, J., Izarra, C., 2002. The crustal structure of the Guayana shield, Venezuela, from seismic refraction and gravity data. Tectonophysics 345, 103-118.

Sobolev, N.V., Efimova, E.S., Channer, D.M.DeR., Anderson, P.F.N., Barron, K.M., 1998. Unusual upper mantle beneath Guaniamo, Guayana Shield, Venezuela: evidence from diamond inclusions. Geology 26 : 971-974.

Spence, D.A., Turcotte, D.L., 1990. Buoyancy-driven magma fracture: A mechanism for ascent through the lithosphere and the emplacement of diamonds. Jnl. Geophys. Research. 95, B4: 5133-5139.

Tassinari, C.C., Macambira, M.J., 1999. Geochronological provinces of the Amazonian craton. Episodes, 22, No. 3: $174-182$.

Contact: DMDeR Channer, Centro Gerencial Mohedano, Oficina 9D, Calle Los Chaguarramos, Urb. La Castellana, Caracas, Venezuela 1060, E-mail: dchanner@genesisbci.net 